\title{
Strategi Pengembangan Potensi Wisata Desa Bone-Bone Kabupaten Enrekang Provinsi Sulawesi Selatan
}

\author{
Aprilya Fitriani, Amelia Savira \\ Institut Agama Islam Negeri Jember \\ aprilya.fitriani@iain-jember.ac.id
}

\begin{abstract}
Bone-Bone Village was known as a non-smoking village in Indonesia. Bone-Bone becomes a tourist area through the district government policy. But it has limitations so that tourism potential was not developed. This study used a descriptive method with a qualitative approach. Methods of analysis used SWOT analysis. The SO strategy described that the community needs to build a road map and a masterplan for the Bone-Bone tourism area. ST's strategy described the need for strategic cooperation between tourist areas in South Sulawesi Province. WO's strategy described the need to educate local communities about recognizing and managing the tourism potential of Bone-Bone. And the strategy of WT saw the need for strategic cooperation with private parties and investors for the development of Bone-Bone tourism area. To implement this strategy required synergies between local communities, governments, and private parties. Therefore, policy recommendations need to pay attention to human resources competence, social and cultural characteristics, and market characteristics for the advancement of tourism villages.
\end{abstract}

Keyword: Tourism Village, SWOT Analysis, Local Community.

\section{Abstrak}

Kampung Bone-Bone dikenal sebagai kampung bebas rokok di Indonesia. BoneBone menjadi kawasan wisata melalui kebijakan pemerintah kabupaten. Namun memiliki keterbatasan sehingga potensi wisata tidak berkembang. Penelitian ini menggunakan metode deskriptif dengan pendekatan kualitatif. Metode analisis yang digunakan adalah analisis SWOT. Strategi SO menggambarkan bahwa masyarakat perlu membangun road map dan masterplan kawasan wisata Bone-Bone. Strategi ST menggambarkan perlunya kerjasama strategis antar kawasan wisata di Provinsi Sulawesi Selatan. Strategi WO menggambarkan perlunya mendidik masyarakat lokal tentang mengenali dan mengelola potensi wisata Bone-Bone. Dan strategi WT melihat perlunya kerjasama strategis dengan pihak swasta dan investor untuk pengembangan kawasan wisata Bone-Bone. Untuk mengimplementasikan strategi ini diperlukan sinergi antara masyarakat lokal, pemerintah, dan pihak swasta. Oleh karena itu, rekomendasi kebijakan perlu memperhatikan kompetensi sumber daya manusia, karakteristik sosial budaya, dan karakteristik pasar untuk kemajuan desa wisata.

Kata Kunci: Desa Wisata, Analisis SWOT, Masyarakat Lokal. 


\section{Pendahuluan}

Sektor pariwisata merupakan salah satu sektor unggulan Indonesia. Memiliki adat, budaya, suku, dan bahasa menjadikan Indonesia unggul dalam sektor pariwisata dunia. Adanya keberagaman inilah yang membuat industri pariwisata Indonesia terus berkembang. Kebudayaan dan adat istiadat yang telah mengakar disetiap sendi kehidupan masyarakat memunculkan ide maupun tren baru disektor pariwisata Indonesia, yaitu Desa Wisata. Keunggulan desa wisata salah satunya menawarkan kegiatan pariwisata yang memberikan manfaat lebih bagi wisatawan, karena mereka akan memperoleh pengalaman visual yang bermanfaat bagi pemahaman mereka mengenai pelestarian lingkungan dan budaya masyarakat. ${ }^{1}$

Desa Bone-Bone merupakan salah satu desa yang berada di Kecamatan Baraka Kabupaten Enrekang Provinsi Sulawesi Selatan. Desa Bone-Bone merupakan salah satu desa percontohan sebagai Desa Bebas Asap Rokok di Indonesia. Hal ini didukung dengan pengakuan dari organisasi kesehatan dunia atau WHO sebagai desa dengan gaya hidup sehat (Lifestyle Without Tobacco) pada tahun 2012. Adanya pengakuan dari dunia internasional tersebut merupakan peluang bagi Desa Bone-Bone menjadi Desa Wisata yang mengenalkan pada wisawatan tentang pentingnya kesehatan dan pelestarian lingkungan. Selain itu, kualitas udara yang bersih, rendahnya polusi udara, kondisi alam yang masih asli, serta adat istiadat yang dijaga ketat oleh masyarakat merupakan potensi Desa BoneBone yang dapat dikembangkan lebih lanjut sebagai salah satu kawasan wisata di Provinsi Sulawesi Selatan.

Melalui berbagai kelebihan yang dimiliki Desa Bone-Bone, menarik dilakukan kajian lebih lanjut mengenai strategi yang dibutuhkan dalam mengembangkan potensi wisata Desa Bone-Bone. Pengembangan kawasan wisata membutuhkan sinergi berbagai pihak. Namun yang lebih utama kesadaran masyarakat dalam mengenali dan memahami potensi wisata di daerahnya, melalui pemahaman sumber daya internal serta faktor eksternal. Oleh karena itu, analisis faktor internal dan eksternal dalam memahami potensi wisata Desa Bone-Bone menarik untuk dilakukan.

Namun, mayoritas desa wisata di Indonesia memiliki keterbatasan dalam pengembangannya. Keterbatasan ini juga terdapat di Desa Bone-Bone. Minimnya infrastruktur bagi para wisatawan, pemasaran kawasan wisata yang kurang gencar, serta tidak adanya destinasi wisata atau even budaya yang ditawarkan Desa BoneBone merupakan salah satu alasan minimnya wisatawan yang mengunjungi Desa Bone-Bone. Oleh karena itu dibutuhkan pemetaan masalah (kelemahan) kawasan wisata Desa Bone-Bone.

${ }^{1}$ Hani Ernawati dan Sela Apriliyani Mahmudah, "Strategi Pengembangan Wisata Seni \& Kerajinan Kasongan, Bangunjiwo, Bantul Yogyakarta", Jurnal Kepariwisataan, Volume 10 Nomor 3, (2016), 49. 
Dalam rangka membantu menyusun strategi pengembangan potensi wisata Desa Bone-Bone, maka perlu dilakukan analisis kekuatan serta kelemahan menggunakan matrik IFAS. Selain itu perlu menganalisis peluang dan ancaman bagi pengembangan kawasan wisata menggunakan matrik EFAS. Strategi pengembangan desa wisata penting dilakukan karena dapat meningkatkan taraf hidup serta kesejahteraan ekonomi masyarakat. Melalui analisis faktor internal dan eksternal, penelitian ini bertujuan untuk memetakan keunggulan (kelemahan) dan peluang (ancaman) Desa Bone-Bone sebagai kawasan wisata strategis di Kabupaten Enrekang. Melalui analisis sumber daya internal dan faktor ekternal, dapat disusun alternatif strategi pengembangan kawasan wisata Desa Bone-Bone sebagai objek wisata yang menarik minat wisatawan lokal hingga mancanegara.

\section{Metode Penelitian}

\section{Metode Pengumpulan Data}

Penelitian dilakukan di Desa Bone-Bone Kecamatan Baraka, Kabupaten Enrekang, Provinsi Sulawesi Selatan pada bulan Maret 2020. Penelitian ini menggunakan metode deskriptif dengan pendekatan kualitatif. Penelitian kualitatif merupakan penelitian yang bermaksud memahami fenomena tentang apa yang dialami oleh subjek penelitian, secara holistik dan dengan cara deskripsi dalam bentuk kata-kata dan bahasa, pada suatu konteks khusus yang alamiah dan dengan memanfaatkan berbagai metode alamiah. ${ }^{2}$ Tujuan dari penelitian deskriptif adalah untuk membuat deskripsi, gambaran atau lukisan secara sistematis, faktual, dan akurat mengenai fakta-fakta, sifat-sifat serta hubungan antar fenomena yang diselidiki. $^{3}$

Teknik pengumpulan data yaitu observasi, penyebaran kuesioner, wawancara, dan dokumentasi. Data sekunder berupa data administrasi Desa Bone-Bone yang berkaitan dengan topik penelitian. Sedangkan data primer berupa hasil kuesioner dan wawancara pada warga Desa Bone-Bone. Kemudian dari hasil wawancara dilakukan perhitungan skor pada faktor internal dan eksternal, hingga menemukan strategi yang sesuai untuk pengembangan potensi wisata Desa Bone-Bone.

\section{Teknik Pengambilan Sampel}

Teknik pengambilan sampel dilakukan secara purposive sampling. Kriteria penentuan sampel yaitu 1) perangkat desa, 2) penduduk asli Desa Bone-Bone yang tinggal dan menetap di Desa Bone-Bone, 3) penduduk asli Desa Bone-Bone minimal berusia 30 tahun. Sehingga sampel penelitian yang diperoleh sebanyak 30 sampel.

${ }^{2}$ Lexy J. Moleong, Metode Penelitian Kualitatif Edisi Revisi (Bandung : PT Remaja Rosda Karya, 2018), 6.

${ }^{3}$ Moh. Nazir, Metode Penelitian (Bogor: Ghalia Indonesia, 2013), 43. 


\section{Metode Analisis Data}

Metode analisis data menggunakan analisis SWOT (strength-weaknessopportunity-threat) untuk mengindentifikasi berbagai faktor secara sistematis dalam rangka merumuskan strategi perusahaan atau organisasi. Analisis SWOT membandingkan antara faktor eksternal (peluang dan ancaman) dengan faktor internal (kekuatan dan kelemahan) sehingga dari analisis tersebut dapat diambil suatu keputusan strategi suatu organisasi. ${ }^{4}$ Analisis SWOT didasarkan pada logika dapat memaksimalkan kekuatan (strength) dan peluang (opportunity), namun secara bersamaan dapat meminimalkan kelemahan (weakness) dan ancaman (threats). ${ }^{5}$ Tahapan melakukan analisis SWOT yaitu :

\section{a. Menentukan Faktor Internal dan Eksternal}

Faktor internal diperoleh dari menganalisis kekuatan dan kelemahan sumber daya internal organisasi. Faktor eksternal berdasarkan analisis peluang dan ancaman (risiko) yang berasal dari luar organisasi.

b. Menyusun matrik IFAS (Internal Factor Analysis Summary) dan EFAS (External Factor Analysis Summary) yaitu :

1) Menentukan faktor-faktor yang menjadi kekuatan serta kelemahan organisasi.

2) Memberi bobot masing-masing faktor tersebut dengan skala $1,0-0,0$ (paling penting sampai dengan tidak penting). Semua bobot bila dijumlahkan tidak melebihi total skor $=1,00$. Faktor-faktor tersebut diberi bobot berdasarkan kemungkinan yang dapat memberikan dampak pada faktor strategis.

3) Menghitung rating untuk masing-masing faktor dengan memberikan skala mulai 4 (outstanding) sampai dengan 1 (poor), berdasarkan pengaruh faktor tersebut berdasarkan kondisi di Desa Bone-Bone. Pemberian nilai rating untuk faktor peluang bersifat positif (peluang yang semakin besar diberi rating +4 , tetapi jika peluangnya kecil, diberi rating +1 ). Pemberian nilai rating ancaman adalah kebalikannya. Misalnya, jika nilai ancamannya sangat besar, nilai rating adalah 1 . Sebaliknya, jika ancamannya sedikit nilai rating adalah 4.

4) Mengalikan bobot $\mathrm{x}$ rating untuk memperoleh faktor pembobotan. Hasilnya berupa skor pembobotan untuk masing-masing faktor yang nilainya bervariasi mulai dari 4,0 (outstanding) sampai dengan 1,0 (poor).

5) Menjumlahkan skor pembobotan, untuk mendapatkan total skor pembobotan bagi organisasi yang bersangkutan. Nilai total ini menunjukkan

${ }^{4}$ Freddy Rangkuti, SWOT Balance Score Card Teknik Menyusun Strategi Korporat Yang Efektif plus Cara Mengelola Kinerja dan Risiko (Jakarta : PT Gramedia Pustaka Utama, 2018), 197.

${ }^{5}$ Freddy Rangkuti, Analisis SWOT Teknik Membedah Kasus Bisnis, Cetakan ke-24 (Jakarta : PT Gramedia Utama, 2018), 19. 
bagaimana suatu organisasi bereaksi terhadap faktor-faktor strategis eksternalnya.

\section{Hasil Penelitian}

\section{Faktor Internal dan Faktor Eksternal}

Faktor internal merupakan faktor-faktor yang berasal dari lingkungan organisasi yang berupa kekuatan (strength) dan kelemahan (weakness) dari potensi wisata Desa Bone-Bone. Tabel 1 menunjukkan faktor internal dari potensi wisata Desa Bone-Bone :

\section{Tabel 1 Faktor Internal}

\begin{tabular}{cll}
\hline No & Kekuatan (Strength) & Kelemahan (Weakness) \\
\hline 1 & $\begin{array}{l}\text { Peraturan Daerah Kabupaten Enrekang } \\
\text { Nomor 14 Tahun 2011 Tentang Rencana Tata } \\
\text { Ruang Wilayah Kabupaten Enrekang Tahun } \\
2011-2031 \text { Pasal 32 }\end{array}$ & $\begin{array}{l}\text { Pengembangan kawasan wisata oleh } \\
\text { Pemerintah Daerah berjalan lamban } \\
\text { bahkan statis }\end{array}$ \\
\hline 2 & $\begin{array}{l}\text { Kesadaran masyarakat menerapkan } \\
\text { lingkungan bebas asap rokok }\end{array}$ & $\begin{array}{l}\text { Minimnya sarana dan prasarana } \\
\text { penunjang kawasan wisata Desa Bone- } \\
\text { Bone }\end{array}$ \\
\hline 3 & $\begin{array}{l}\text { Kesadaran masyarakat menjaga budaya dan } \\
\text { adat istiadat setempat }\end{array}$ & $\begin{array}{l}\text { Minimnya penguasaan teknologi oleh } \\
\text { masyarakat }\end{array}$ \\
\hline 4 & Sumber daya alam yang masih alami & $\begin{array}{l}\text { Minimnya pengetahuan masyarakat } \\
\text { tentang pengembangan kawasan wisata }\end{array}$ \\
\hline 5 & Produk unggulan Kopi Bone-Bone & \\
\hline & Sumber : Hasil observasi peneliti & \\
\end{tabular}

Sedangkan faktor eksternal merupakan faktor-faktor yang berasal dari luar organisasi berupa peluang (opportunity) dan ancaman (threat) yang berdampak pada eksistensi potensi wisata di Desa Bone-Bone. Tabel 2 menunjukkan faktor eksternal dari potensi wisata Desa Bone-Bone :

\section{Tabel 2 Faktor Eksternal}

\begin{tabular}{cll}
\hline No & Peluang (Opportunity) & Ancaman (Threat) \\
\hline 1 & $\begin{array}{l}\text { Pengakuan dari WHO sebagai desa dengan } \\
\text { lifestyle without tobacco }\end{array}$ & Bencana alam \\
\hline 2 & Kunjungan wisatawan luar negeri & Kerusakan lingkungan \\
\hline 3 & APBDes untuk pengembangan desa & $\begin{array}{l}\text { Persaingan desa wisata dengan kawasan } \\
\text { atau provinsi lain }\end{array}$ \\
\hline 4 & Peluang investasi oleh investor & \\
\hline Sumber : Hasil observasi peneliti &
\end{tabular}

\section{Matrik IFAS dan EFAS}

Tahap selanjutnya yaitu perhitungan bobot dan rating pada faktor internal dan eksternal. Perhitungan bobot ini bertujuan untuk memberikan nilai atau bobot mengenai seberapa besar pengaruh masing-masing pernyataan yang disusun pada 
internal dan eksternal organisasi terhadap kesuksesan organisasi. Pemberian bobot mulai dari 1,0 (sangat penting) sampai 0,0 (tidak penting). Formulasi untuk menentukan bobot apabila penelitian tersebut menggunakan kuesioner sebagai pengumpul data yaitu : ${ }^{6}$

$$
\text { Bobot }=\frac{\text { Nilai Pengolahan Data Kuesioner }}{\text { Total Nilai Pengolahan Data Kuesioner }}
$$

Untuk menentukan rating, dilakukan dengan memberikan skala mulai dari 4 (outstanding) sampai dengan 1 (poor), berdasarkan pengaruh faktor terhadap kondisi organisasi. Untuk memperoleh skor pembobotan, maka dilakukan pengalian antara bobot dan rating.

$$
\text { Skor }=\text { Bobot } X \text { Rating }
$$

Pada tabel berikut ini disajikan formulasi bobot, rating, hingga skor untuk menyusun matrik IFAS dan EFAS.

Tabel 3 Matrik IFAS

\begin{tabular}{clccc}
\hline No & \multicolumn{1}{c}{ Kekuatan (Strength) } & Bobot & Rating & Skor \\
\hline 1 & $\begin{array}{l}\text { Peraturan Daerah Kabupaten Enrekang Nomor 14 } \\
\text { Tahun 2011 Tentang Rencana Tata Ruang Wilayah } \\
\text { Kabupaten Enrekang Tahun 2011-2031 Pasal 32 }\end{array}$ & & 4 & 0,55 \\
\hline 2 & $\begin{array}{l}\text { Kesadaran masyarakat menerapkan lingkungan bebas } \\
\text { asap rokok }\end{array}$ & 0,12 & 4 & 0,46 \\
\hline 3 & $\begin{array}{l}\text { Kesadaran masyarakat menjaga budaya dan adat istiadat } \\
\text { setempat }\end{array}$ & 0,11 & 3 & 0,33 \\
\hline 4 & Kondisi geografis yang masih alami & 0,10 & 2 & 0,20 \\
\hline 5 & Produk unggulan Kopi Bone-Bone & 0,11 & 3 & 0,34 \\
\hline & Total Perhitungan Bobot Kekuatan (Strength) & $\mathbf{0 , 5 7}$ & & $\mathbf{1 , 8 8}$ \\
\hline
\end{tabular}

\begin{tabular}{clccr}
\hline No & \multicolumn{1}{c}{ Kelemahan (Weakness) } & Bobot & Rating & Skor \\
\hline 1 & $\begin{array}{l}\text { Pengembangan kawasan wisata oleh Pemerintah Daerah } \\
\text { berjalan lamban bahkan statis }\end{array}$ & 0,11 & 2 & 0,22 \\
\hline 2 & $\begin{array}{l}\text { Minimnya sarana dan prasarana penunjang kawasan } \\
\text { wisata Desa Bone-Bone }\end{array}$ & 0,12 & 3 & 0,35 \\
\hline 3 & Minimnya penguasaan teknologi oleh masyarakat & 0,10 & 2 & 0,20 \\
\hline 4 & $\begin{array}{l}\text { Minimnya pengetahuan masyarakat tentang } \\
\text { pengembangan kawasan wisata }\end{array}$ & 0,10 & 3 & 0,30 \\
\hline & Total Perhitungan Bobot Kelemahan (Weakness) & $\mathbf{0 , 4 3}$ & & $\mathbf{1 , 0 7}$ \\
\hline
\end{tabular}

${ }^{6}$ Hermanto, “Analisis SWOT Obat Batuk Prospan Pada PT Soho Global Health”, Jurnal Metris No. 17 (2016), 15. 
Sumber : Hasil olah data peneliti

Tabel 4 Matrik EFAS

\begin{tabular}{|c|c|c|c|c|}
\hline No & Peluang (Opportunity) & Bobot & Rating & Skor \\
\hline 1 & $\begin{array}{l}\text { Pengakuan dari WHO sebagai desa dengan lifestyle } \\
\text { without tobacco }\end{array}$ & 0,17 & 4 & 0,67 \\
\hline 2 & Kunjungan wisatawan luar negeri & 0,16 & 3 & 0,47 \\
\hline 3 & APBDes untuk pengembangan desa & 0,14 & 2 & 0,29 \\
\hline \multirow[t]{2}{*}{4} & Peluang investasi oleh investor & 0,13 & 2 & 0,27 \\
\hline & Total Perhitungan Bobot Peluang (Opportunity) & $\mathbf{0 , 6 0}$ & & 1,69 \\
\hline No & Ancaman (Threat) & Bobot & Rating & Skor \\
\hline 1 & Bencana alam & 0,14 & 3 & 0,41 \\
\hline 2 & Kerusakan lingkungan ulah wisatawan & 0,12 & 4 & 0,49 \\
\hline 3 & $\begin{array}{l}\text { Persaingan desa wisata dengan kawasan atau provinsi } \\
\text { lain }\end{array}$ & 0,14 & 2 & 0,28 \\
\hline & Total Perhitungan Bobot Ancaman (Threat) & $\mathbf{0 , 4 0}$ & & 1,18 \\
\hline & Total Perhitungan Matrik EFAS & 1,00 & & 2,87 \\
\hline
\end{tabular}

Sumber : Hasil olah data peneliti

Tahap selanjutnya yaitu menentukan dimana posisi strategis Desa Bone-Bone sebagai kawasan wisata. Untuk menentukan posisi organisasi dalam matriks SWOT, maka dilakukan dua perhitungan sebagai berikut. Pertama, menjumlahkan total skor kekuatan dengan total skor kelemahan, diasumsikan bahwa skor kekuatan bernilai positif, sedangkan skor kelemahan bernilai dominan. Jika hasilnya positif, maka faktor kekuatan lebih dominan. Kedua, menjumlahkan total skor peluang dengan total skor ancaman, diasumsikan skor peluang bernilai positif, sedangkan skor ancaman bernilai dominan. Jika hasilnya positif, maka faktor peluang lebih dominan. Sebaliknya, jika hasilnya dominan, maka faktor ancaman lebih dominan. ${ }^{7}$ Formulasi perhitungan skor kekuatan-kelemahan $(\mathrm{S}-\mathrm{W})$ dan peluang-ancaman $(\mathrm{P}-$ W) ditunjukkan pada Tabel 5 berikut ini :

Tabel 5 Skor IFAS dan EFAS

\begin{tabular}{lclc}
\multicolumn{1}{c}{ IFAS } & \multicolumn{2}{c}{ EFAS } \\
\hline \multicolumn{1}{c}{ Kategori } & Sub Total & \multicolumn{1}{c}{ Kategori } & Sub Total \\
\hline Kekuatan $(\mathrm{S})$ & 1,88 & Peluang $(\mathrm{O})$ & 1,69 \\
\hline Kelemahan $(\mathrm{W})$ & 1,07 & Ancaman $(\mathrm{T})$ & 1,18 \\
\hline Total $(\mathbf{S}-\mathrm{W})$ & $\mathbf{0 , 8 1}$ & Total $(\mathbf{O}-\mathbf{T})$ & $\mathbf{0 , 5 1}$ \\
\hline
\end{tabular}

Sumber : Hasil olah data peneliti

7 Tjia Fie Tjoe dan Haryadi Sarjono, "Strategi Isnis Pada PT CTL Dengan Pendekatan Metode TOWS”, BINUS BUSINESS REVIEW, Vol.1 No.2 (November 2010), 434-447. 
Berdasarkan hasil perhitungan yang ditunjukkan pada Tabel 5, diperoleh nilai Kekuatan-Kelemahan (S-W) sebesar 0,81. Selanjutnya nilai tersebut akan menjadi nilai di sumbu X. Sedangkan nilai Peluang-Ancaman (O-T) sebesar 0,51 yang menjadi nilai di sumbu Y dalam diagram analisis SWOT berikut ini :

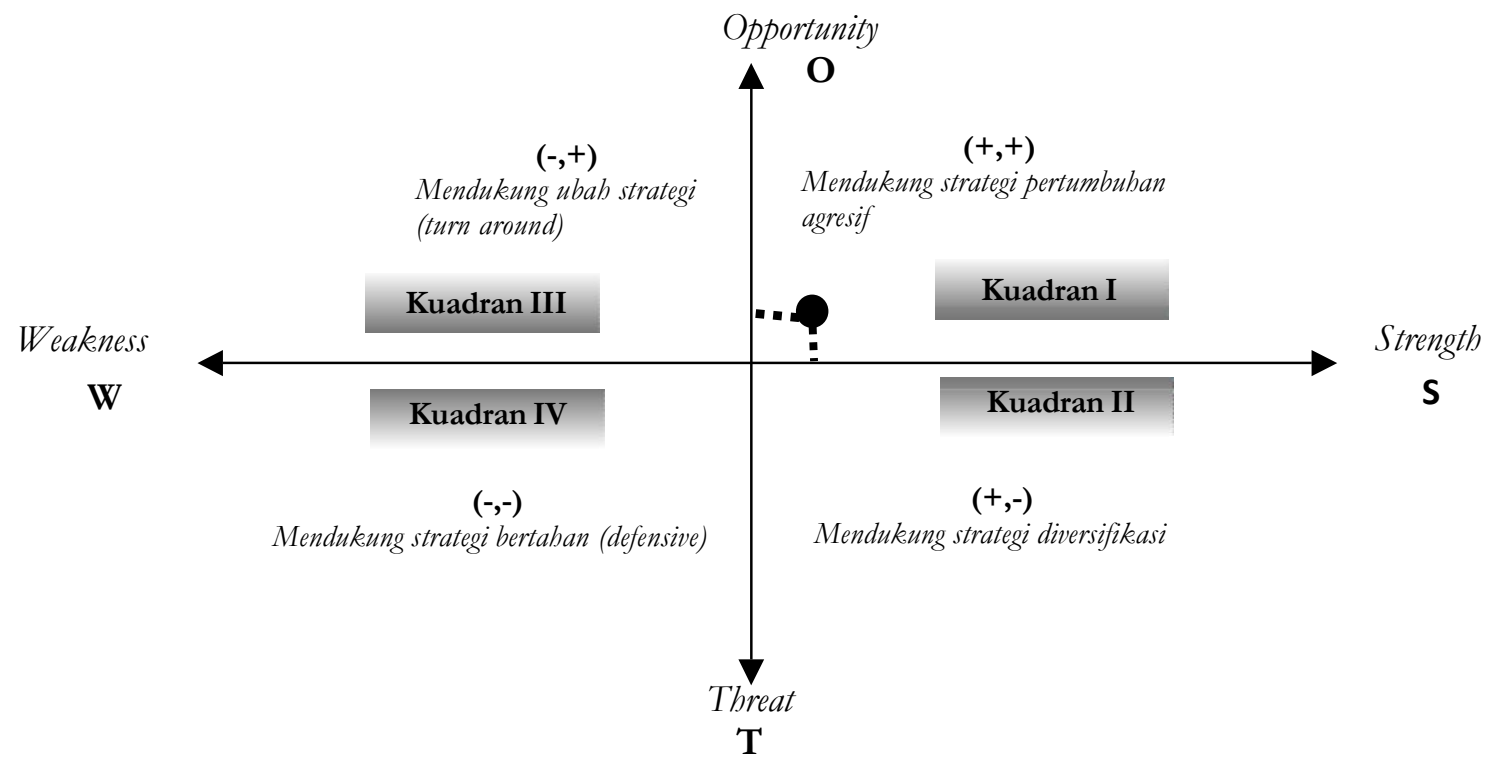

Gambar 1 Diagram Analisis SWOT

Sumber : Freddy Rangkuti (2018), 20

Berdasarkan perhitungan yang ditunjukkan di Tabel 5, posisi kawasan wisata Desa Bone-Bone berada di Kuadran I. Pada posisi ini organisasi memiliki peluang dan kekuatan sehingga dapat memanfaatkan peluang yang ada. ${ }^{8}$ Artinya Desa Bone-Bone memiliki kelebihan dibandingkan kawasan wisata lainnya. Salah satu kelebihan Desa Bone-Bone yaitu menjadi percontohan Desa Bebas Asap Rokok di Indonesia dan telah diakui oleh dunia melalui WHO. Melalui salah satu kelebihan ini, Desa Bone-Bone dapat memanfaatkan peluang sebagai kawasan wisata pendidikan dan kesehatan yang dapat menarik keinginan wisatawan domestik dan luar negeri untuk mengunjungi Desa Bone-Bone.

\section{Diskusi}

\section{Analisis SWOT}

Berdasarkan analisis faktor internal dan eksternal yang terdapat di Desa Bone-Bone, maka disusun alternatif strategi berdasarkan pertimbangan kombinasi

\footnotetext{
${ }^{8}$ Freedy Rangkuti, op.cit, 20-21.
} 
empat faktor strategis dalam mengembangkan potensi wisata Desa Bone-Bone sebagai berikut :

a. Strategi SO (Strength Opportunity)

Strategi ini berupaya untuk memanfaatkan kekuatan yang dimiliki untuk meraih peluang-peluang yang ada di lingkungan eksternal. ${ }^{9}$ Alternatif strategi yang dapat digunakan yaitu :

1) Menyusun Roadmap dan Masterplan pengembangan kawasan wisata Desa Bone-Bone.

2) Edukasi bersama aparat desa tentang strategi optimalisasi anggaran desa untuk peningkatan kawasan wisata.

3) Edukasi pada generasi penerus maupun wisatawan tentang pentingnya kawasan bebas asap rokok.

4) Kerjasama strategis antar kawasan wisata guna memasarkan produk unggulan tiap desa.

b. Strategi ST (Strength Threat)

Strategi ini memanfaatkan kekuatan yang dimiliki organisai untuk menghadapi ancaman dari eksternal. ${ }^{10}$ Alternatif strategi yang dapat digunakan yaitu :

1) Melakukan penataan ruang dan pembangunan kawasan wisata dengan memperhatikan peta rawan bencana (mitigasi bencana).

2) Sosialisasi sanksi terhadap wisatawan yang merusak lingkungan .

3) Kerjasama strategis atau Memorandum of Understanding (MoU) antar kawasan wisata di Provinsi Sulawesi Selatan tentang strategi pengembangan kawasan wisata.

c. Strategi WO (Weakness Opportunity)

Strategi yang dirancang ialah berusaha meminimalkan kelemahan dengan memanfaatkan peluang yang ada. ${ }^{11}$ Alternatif strategi yang ditawarkan yaitu :

1) Kerjasama strategis atau Memorandum of Understanding (MoU) dengan pihak investor untuk membantu pembangunan kawasan wisata Desa Bone-Bone.

2) Edukasi pemanfaatan teknologi pada masyarakat untuk pengembangan kawasan wisata.

3) Edukasi pada masyarakat tentang strategi mengenali dan mengelola potensi wisata khususnya di Desa Bone-Bone.

d. Strategi WT (Weakness Threat)

Strategi ini bertujuan untuk menekan kelemahan dan mencegah ancaman dari

\footnotetext{
${ }^{9}$ Hani Ernawati dan Sela Apriliyani Mahmudah, op.cit, 49-64.

${ }^{10} \mathrm{Ibid}, 49-64$.

${ }^{11}$ Ibid, 49-64.
} 
Strategi Pengembangan Potensi Wisata ...

\begin{tabular}{|c|c|c|}
\hline $\begin{array}{l}\text { pengembangan desa } \\
\text { 4. Peluang investasi } \\
\text { oleh investor }\end{array}$ & $\begin{array}{l}\text { desa untuk peningkatan } \\
\text { kawasan wisata } \\
\text { 3. Edukasi pada generasi } \\
\text { penerus } \\
\text { wisatawan maupun } \\
\text { pentingnya tentang } \\
\text { bebas asap rokok } \\
\text { 4. Kerjasama strategis antar } \\
\text { kawasan wisata guna } \\
\text { memasarkan produk } \\
\text { unggulan tiap desa }\end{array}$ & $\begin{array}{l}\text { 2. Edukasi pemanfaatan } \\
\text { teknologi } \\
\text { masyarakat } \\
\text { pengembangan kawasan } \\
\text { wisata } \\
\text { 3. Edukasi pada masyarakat } \\
\text { tentang strategi mengenali } \\
\text { dan mengelola potensi } \\
\text { wisata khususnya di Desa } \\
\text { Bone-Bone }\end{array}$ \\
\hline \begin{tabular}{lr}
\multicolumn{1}{c}{ Threat $(\boldsymbol{T})$} \\
1. Bencana alam \\
2. Kerusakan \\
lingkungan ulah \\
wisatawan \\
3. Persaingan desa \\
wisata dengan \\
kawasan atau provinsi \\
lain
\end{tabular} & $\begin{array}{l}\text { Strategi ST } \\
\text { 1. Melakukan penataan } \\
\text { ruang dan pembangunan } \\
\text { kawasan wisata dengan } \\
\text { memperhatikan peta } \\
\text { rawan bencana (mitigasi } \\
\text { bencana) } \\
\text { 2. Sosialisasi sanksi } \\
\text { terhadap wisatawan yang } \\
\text { merusak lingkungan } \\
\text { 3. Kerjasama strategis atau } \\
\text { Memorandum } \\
\text { Understanding (MoU) } \\
\text { antar kawasan wisata di } \\
\text { Provinsi Sulawesi Selatan } \\
\text { tentang strategi } \\
\text { pengembangan kawasan } \\
\text { wisata }\end{array}$ & 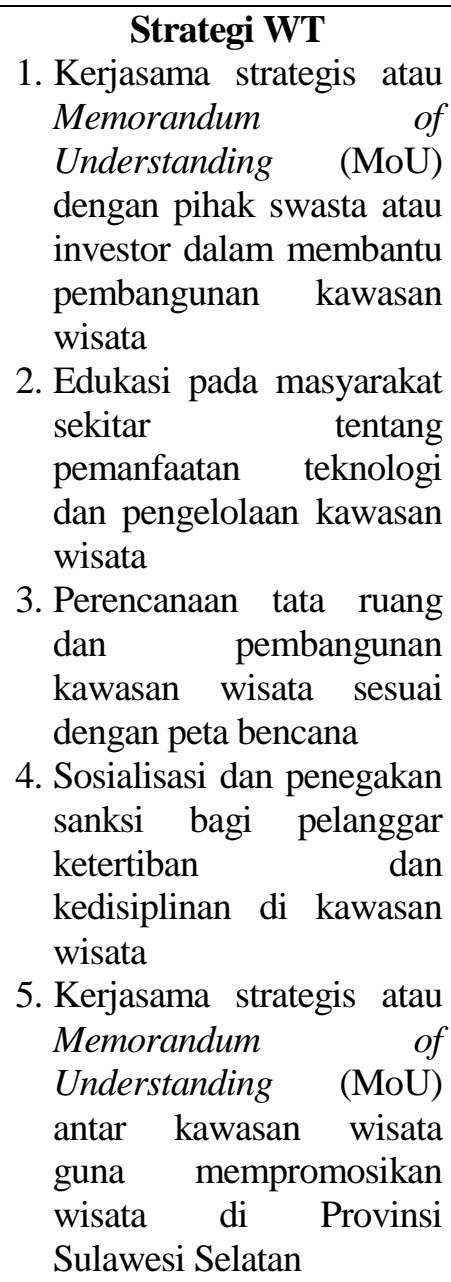 \\
\hline
\end{tabular}

Sumber : Hasil analisis peneliti

\section{Analisis Rekomendasi Kebijakan}

Implementasi strategi membutuhkan kerjasama dan sinergi dari berbagai pihak, yaitu masyarakat setempat, pemerintah, serta dukungan dari pihak swasta. Karena pengembangan kawasan wisata tidak dapat berjalan tanpa dukungan dari 
pihak-pihak tersebut. Melalui peran masyarakat, kebijakan pemerintah, serta dukungan pihak swasta, akan menghasilkan rekomendasi kebijakan yang sesuai dengan potensi pengembangan kawasan wisata Desa Bone-Bone. Analisis peran serta rekomendasi kebijakan berdasarkan kompetensi sumber daya manusia, karakteristik sosial dan budaya, serta karakteristik pasar ditunjukkan pada Gambar 2 berikut ini :

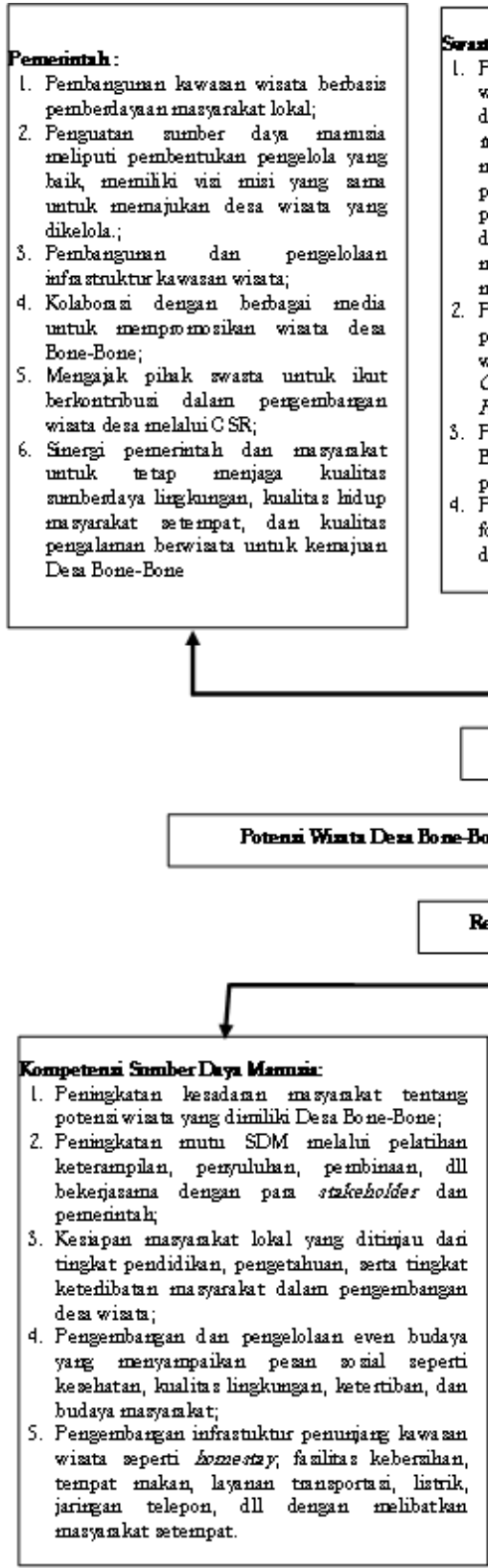

\section{Srath :}

Pengembangan kawa an wiata Desa Bone-Bone dengan prinip sIsteine b5 on Ixim development, yaus tnenekankatn pada perlindungand dan pengelolaan kawasan wiata dalann janteka panjang dan melibatkan penten pe int ma syarakat sekitar;

Pembanguman dan pengembangan kawa an wisata tnelalui progrn Corporate Socer Responsibility (CSR);

3. Pembinaan mazramkat Desa Bone-Bone bersana dengan pihak pemerintah;

A. Participaxi aktif dalan forum kotmunikaxi warga desa.
Mexpinat :

l. Melakukan edukaxi yang bedkelanjutan pad a generazi mmida, yate dimulai dari lingkurean keluara tentang pentingnya mexjaga linghoungan yang bebas aap mokok;

2. Pemberlayaan mazyankat melalui komutrita lomurita s untuk tmengelola, tre rijga, dan mena arkan Dea Bone-Bone sebagai Desa Wiats;

3. Penguatan budaya demean memahami keurikan budaya dan mengenalkan budaya melalui even budaya;

d. Melakukan inova mi yang berkelanjutan berbacis kearifan budaya lokal;

5. Menciptakan ote ntixita s produk dan orixinalita $a$ even budaya se bagai simbol keunikan Desa Bone-Bone;

6. Menjalin kejazama dengan pihak akademizi, penelitian, pendampingan pe mberdayaan ma zja a kat, pihak awa sta, maupun bio perjalanan wiata untuk memetalan dan me treembanglan potenci wizata Dea Bone-Bone;

7. Pengelolasn kawasin wisata untuk menjaga keber vilan, keascian, dan keannanan wisatawan

AntirixPenn

T

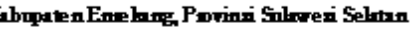

RekomendinKehïglan

\section{r}

Renkterixtik Soxil dnn Bodry

L. Memajukan tingkat hidup masyankat sekligus melestarikan identitas budaya dan tradisi lokal.

2. Menitekatkan æonangat berwimusha, tne miliki inovari, kreativitas maupun semangat memperkenalkan potensi des dan me tegajak onter lain untruk berwiat the De a Bone-bone;

3. Metnpunyai sistem keperayaan dan kema rramkatan tnerupakan aspek penting;

4. Memegang teguh he arifan lokal.

\section{Kankteritits Panr (Den Wimt :}

I. Mermunculkan keaglian budaya lokal untuk dapat tnenciptakan 2mofp nicity experience bagi wiatawan;

2. Promogi dan pemararan kawa an wisats dengan tne treembangkan gistem informa melalui tnedia oetak, media elektrotink, datn tnedi so rial;

3. Pexzena an potenci wizata Bone-Bone dengan memanfaatkan kemajuan teknologi;

d. Membateun frasiong desa wiata melalui

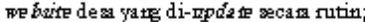

5. Metna adkan produk ungsulan Desa BoneBone tnelalui rrebscic desa, media sosial, æerta keja sama dengan platorm ecomonarce na rional.

6. Strategi pema aran tentate bagaimana pengemaan atmki sobagai daya tarik utama dea wisats, pemazaran amenitnx (fazilitas pendukung) , dan akenhifins aast berwiats ke Dea Bone-Bone. 


\section{Kesimpulan}

Berdasarkan analisis SWOT yang telah dilakukan diperoleh alternatif strategi dalam mengembangkan potensi pariwisata Desa Bone-Bone, yaitu :

1. Strategi SO (Strength Opportunity), alternatif strategi dalam pengembangan potensi wisata Desa Bone-Bone, diantaranya :

a. Menyusun Roadmap dan Masterplan pengembangan kawasan wisata Desa Bone-Bone.

b. Edukasi bersama aparat desa tentang strategi optimalisasi anggaran desa untuk peningkatan kawasan wisata .

c. Edukasi pada generasi penerus maupun wisatawan tentang pentingnya kawasan bebas asap rokok.

d. Kerjasama strategis antar kawasan wisata guna memasarkan produk unggulan tiap desa.

2. Strategi ST (Strength Threat), alternatif strategi diantaranya :

a. Melakukan penataan ruang dan pembangunan kawasan wisata dengan memperhatikan peta rawan bencana (mitigasi bencana).

b. Sosialisasi sanksi terhadap wisatawan yang merusak lingkungan.

c. Kerjasama strategis atau Memorandum of Understanding (MoU) antar kawasan wisata di Provinsi Sulawesi Selatan tentang strategi pengembangan kawasan wisata.

3. Strategi WO (Weakness Opportunity), strategi yang ditawarkan diantaranya :

a. Kerjasama strategis atau Memorandum of Understanding (MoU) dengan pihak investor untuk membantu pembangunan kawasan wisata Desa BoneBone.

b. Edukasi pemanfaatan teknologi pada masyarakat untuk pengembangan kawasan wisata.

c. Edukasi pada masyarakat tentang strategi mengenali dan mengelola potensi wisata khususnya di Desa Bone-Bone.

4. Strategi WT (Weakness Threat), strategi yang ditawarkan diantaranya :

a. Kerjasama strategis atau Memorandum of Understanding (MoU) dengan pihak swasta atau investor dalam membantu pembangunan kawasan wisata.

b. Edukasi pada masyarakat sekitar tentang pemanfaatan teknologi dan pengelolaan kawasan wisata.

c. Perencanaan tata ruang dan pembangunan kawasan wisata sesuai dengan peta bencana.

d. Sosialisasi dan penegakan sanksi bagi pelanggar ketertiban dan kedisiplinan di kawasan wisata.

e. Kerjasama strategis atau Memorandum of Understanding (MoU) antar 
kawasan wisata guna mempromosikan wisata di Provinsi Sulawesi Selatan.

Untuk mengimplementasikan strategi tersebut, peran masyarakat, dukungan pemerintah serta keterlibatan pihak swasta sangat memengaruhi pengembangan potensi wisata Desa Bone-Bone. Oleh karena itu dalam menyusun rekomendasi kebijakan atau program pengembangan kawasan wisata Desa Bone-Bone, hal-hal yang perlu dipertimbangkan yaitu :

1. Kompetensi Sumber Daya Manusia, meliputi :

a. Peningkatan kesadaran masyarakat tentang potensi wisata yang dimiliki Desa Bone-Bone.

b. Peningkatan mutu SDM melalui pelatihan keterampilan, penyuluhan, pembinaan, bekerjasama dengan para stakeholder dan pemerintah.

c. Kesiapan masyarakat lokal yang ditinjau dari tingkat pendidikan, pengetahuan, serta tingkat keterlibatan masyarakat dalam pengembangan desa wisata.

d. Pengembangan dan pengelolaan even budaya yang menyampaikan pesan sosial seperti kesehatan, kualitas lingkungan, ketertiban, dan budaya masyarakat.

e. Pengembangan infrastuktur penunjang kawasan wisata seperti homestay, fasilitas kebersihan, tempat makan, layanan transportasi, listrik, jaringan telepon, dan sebagainya dengan melibatkan masyarakat setempat.

2. Karakteristik Sosial dan Budaya :

a. Memajukan tingkat hidup masyarakat sekaligus melestarikan identitas budaya dan tradisi lokal.

b. Meningkatkan semangat berwirausaha, memiliki inovasi, kreativitas, maupun semangat memperkenalkan potensi desa dan mengajak orang lain untuk berwisata ke Desa Bone-bone.

c. Mempunyai sistem kepercayaan dan kemasyarakatan merupakan aspek penting.

d. Memegang teguh kearifan lokal.

3. Karakteristik Pasar (Desa Wisata) :

a. Memunculkan keaslian budaya lokal untuk dapat menciptakan auntenticity experience bagi wisatawan.

b. Promosi dan pemasaran kawasan wisata dengan mengembangkan sistem informasi melalui media cetak, media elektronik, dan media sosial.

c. Pengemasan potensi wisata Bone-Bone dengan memanfaatkan kemajuan teknologi.

d. Membangun branding desa wisata melalui website desa yang di-update secara rutin.

e. Memasarkan produk unggulan Desa Bone-Bone melalui website desa, media sosial, serta kerja sama dengan platform e-commerce nasional. 
f. Strategi pemasaran tentang bagaimana pengemasan atraksi sebagai daya tarik utama desa wisata, amenitas (fasilitas pendukung), dan aksesibilitas saat berwisata ke Desa Bone-Bone.

Penelitian ini hanya melakukan analisis strategi pengembangan potensi wisata Desa Bone-Bone menggunakan matrik SWOT. Namun terdapat keterbatasan dalam penelitian ini, diantaranya yaitu tidak menganalisis perubahan ekonomi, sosial, dan budaya yang lebih mendalam setelah Desa Bone-Bone dijadikan sebagai desa percontohan bebas asap rokok serta kawasan wisata di Kabupaten Enrekang Provinsi Sulawesi Selatan. Perubahan ini perlu diteliti lebih lanjut, karena keterlibatan masyarakat lokal akan memengaruhi cara pandang, dan tindakan masyarakat dalam merespon perubahan di daerahnya. Oleh karena itu penelitian selanjutnya perlu menganalisis lebih mendalam tentang perubahan kondisi ekonomi, sosial dan budaya masyarakat Desa Bone-Bone sebagai kawasan wisata di Kabupaten Enrekang Provinsi Sulawesi Selatan.

Selain itu, penentuan strategi menggunakan matrik SWOT memiliki kelemahan. Matrik SWOT pada dasarnya disusun untuk menilai kinerja perusahaan atau organisasi yang memiliki profit, yang didasarkan pada faktor internal serta faktor eksternal yang mempengaruhi eksistensi organisasi. Oleh karena itu strategi matrik SWOT kurang membahas secara mendalam mengenai faktor-faktor sosial dan budaya dalam masyarakat. Padahal pengembangan desa wisata selalu melibatkan partisipasi masyarakat secara aktif. Sehingga diharapkan pada penelitian selanjutnya, diperlukan model-model pengembangan desa wisata berdasarkan partisipasi masyarakat.

\section{Daftar Pustaka}

Ahadiyanto, Nuzul. Hubungan Dimensi KepribadianThe Big Five Personality Dengan Tingkat Kesejahteraan Psikologis Narapidana. Jurnal Al-Hikmah, 2020, 18.1: 117-130.

Al Ahsani, Nasirudin. Kepemimpinan Perempuan Pada Masyarakat dalam Perspektif Sa īd Ramaḍān Al-Būṭ̂̄ (Telaah Hadis Misoginis). Jurnal AlHikmah, 2020, 18.1: 57-74.

Alwi, Muhammad Muhib. Pemberdayaan Ekonomi Masyarakat Berbasis Masjid di Tengah Pandemi Covid-19. Jurnal Al-Hikmah, 2020, 18.1: 99-116.

Dawud, Mochammad. Menerapkan Manajemen Strategi Penyiaran untuk Penyiaran Dakwah. Jurnal Al-Hikmah, 2019, 17.1: 109-140.

Dawud, Mochammad; Choliq, Abdul. Manajemen Strategi Ala NU Tv 9 Menghadapi Televisi Swasta Lokal di Surabaya. Jurnal Al-Hikmah, 2020, 18.1: 75-98.

Elanda, Yelly. Komodifikasi Agama pada Perumahan Syariah di Surabaya. Jurnal Al-Hikmah, 2019, 17.1: 41-62. 
Ernawati, H., \& Mahmudah, S. A. (2016). Strategi pengembangan desa wisata seni \& kerajinan kasongan, bangunjiwo, bantul, yogyakarta. Jurnal Kepariwisataan, 10, 49-64. http://ejournal.stipram.ac.id/index.php/ kepariwisataan/article/view/91

Fauzi, Ahmad. Problematika Dakwah di Tengah Pandemi Covid 19 Mewabah. Jurnal Al-Hikmah, 2020, 18.1: 27-36.

Hadi, H. Sofyan. Manajemen Strategi Dakwah di Era Kontemporer. Jurnal AlHikmah, 2019, 17.1: 79-90.

Hermanto, A. R. K. (2016). Analisis SWOT Obat Batuk Prospan pada PT. Soho Global Health. Jurnal Metris, 5(9), 1689-1699. https://doi.org/10.1017/CBO9781107415324.004

Isfironi, Mohammad. Kota Santri, Bumi Shalawat Nariyah dan Bule-Dhika. Jurnal Al-Hikmah, 2019, 17.1: 1-20.

Jannah, Hasanatul. Pondok Pesantren Sebagai Pusat Otoritas Ulama Madura. Jurnal Al-Hikmah, 2019, 17.1: 91-108.

Kuncoro, Mudrajat. Strategi Bagaimana Meraih Keunggulan Kompetitif. Jakarta : Penerbit Erlangga, 2005.

Moleong, Lexy J. Metode Penelitian Kualitatif Edisi Revisi. Bandung : PT Remaja Rosda Karya, 2018.

Nazir, Moh. Metode Penelitian. Bogor : Ghalia Indonesia, 2013.

Rangkuti, Freddy. Analisis SWOT Teknik Membedah Kasus Bisnis, Cetakan ke-24. Jakarta : PT Gramedia Utama, 2018.

Rangkuti, Freddy. SWOT Balance Score Card Teknik Menyusun Strategi Korporat Yang Efektif plus Cara Mengelola Kinerja dan Risiko. Jakarta : PT Gramedia Pustaka Utama, 2018.

Setiawan, Eko. Makna Nilai Filosofi Wayang Kulit Sebagai Media Dakwah. Jurnal Al-Hikmah, 2020, 18.1: 37-56.

Tjoe, T. F., \& Sarjono, H. (2010). Strategi Bisnis pada PT CTL Dengan Pendekatan Metode Tows. Binus Business Review, 1(2), 434. https://doi.org/10.21512/bbr.v1i2.1092

Wazis, Kun. Perlawanan Ahli Hadis terhadap Gerakan Radikalisme Dalam Konstruksi Media Online. Jurnal Al-Hikmah, 2019, 17.1: 20-40.f 